\title{
Social Media and Islamic Marketing Towards Customer Satisfaction and Loyalty Impacts in Indonesia
}

\author{
Vika Annisa Qurrata ${ }^{1 *}$ Achmad Murdiono $^{2}$ Nor Ermawati Binti Hussain ${ }^{3}$ Vidya \\ Purnamasari $^{4}$
}

\author{
${ }^{1,2,4}$ Universitas Negeri Malang \\ ${ }^{3}$ Universiti Malaysia Terengganu \\ *Corresponding author. Email: vika.annisa.fe@um.ac.id
}

\begin{abstract}
The operations and success of the business have been influenced by internet technology and social media. The interaction between seller and buyer has been changed since social media influencing the way of marketing. When the sellers know how to maximize their facilitation in behaviors, social media will yield excellent company sales results. Thus, social media involvement has increased. We test the impact of social media and Islamic marketing on customer satisfaction and customer loyalty. Using explanatory research and a quantitative approach, we empirically test a model using path analysis and descriptive analysis. This study took a sample of 140 respondents by purposive sampling technique. The calculation of path analysis showed that not only social media but also Islamic Marketing has an impact on customer satisfaction. Also, customer satisfaction has a positive relationship with customer loyalty. Findings suggest that customer need social media due to its essential role in communicating information. However, Islamic marketing related to social media has to be maintained and improved to enhance company revenue.
\end{abstract}

Keywords: Social Media marketing, Islamic marketing, Customer Satisfaction, Customer Loyalty, Path Analysis

\section{INTRODUCTION}

Indonesia has a total population of 268.2 million, with an estimated increase of $1 \%$ or around 3 million in 2018 [1]. Indonesia's internet users are around 150 million, nearly $13 \%$ of the total population from 2018 . Active Social Media users were 150 million in 2018, and Mobile Social Media users up to 130 million, with an increase of $8.3 \%$ in 2018 [1]. Additionally, Bank Indonesia (BI) launched the online spending of Indonesian people reaching Rp75 trillion over the past year. If it is divided on average by internet users who shop online, each person spends Rp. 3 million per year.

Indonesian and most people in other countries needed for social media applications are rocketing, which is an essential part of their daily lives. Many people choose to move their interactions to virtual platforms rather than in real life (i.e., Facebook, Instagram, LinkedIn, and Twitter). It is, in turn, their social media choice positively reflects people's orientations and behaviors regarding various social media applications $[2 ; 3 ; 4 ; 5 ; 6 ; 7]$.
Therefore, social media applications have been assessed as one of the influential things which are progressively involved in any aspect of human lives $[2,4,6,8,9,10$, $11,12]$.

In Alalwan et al. [7], the most efficacious method of firms' marketing purpose and action plan nowadays is social media. It impressed countless aspects of communication, relation management, and customer $[14,15]$. For instance, many firms believe that they can use social media as a strategy to extend two-way communication between firms and customers, anchoring customers with brands. Social media display the subject textually, visually, and verbally with easiness [16]. The circumstances make firms deploy the internet to interact with the customer, such as knowing the buying pattern and consumer behavior [13]. Due to its fact, many companies level up their brand identity and market performance using numerous strategies and ideas $[14,17,18]$.

Indonesia has a high number of e-commerce users, and this country is known as Muslim majority countries. 
Based on data, Indonesia is one of the Muslim majority countries, with $87.2 \%$ of its population [19]. In marketing views, this number has a strategic position and potential to become an opportunity for the business world.

Muslim consumers believe that several rules are tied to them, such as religion and ethics. Life principles followed by Muslims are using religion as a way of life and practice everyday life using Al-Quran and hadith. Its principles have to know and implemented by marketers interested in the Muslim consumer market. Therefore, the marketing strategy has to contain Islamic principles, namely Islamic marketing. In this scheme, equity and justice for people's welfare are blended with ethics and value maximation. Religion and ethics are important for Muslim consumers because they believe that the rules tie them. The religion to Muslim consumers has adopted a belief that provides a set of instructions, way of life, and practices in everyday life that Syumul (perfect). These life principles should be taken into account by marketers interested in the Muslim consumer market. Thus, marketers need different marketing strategy which following Islamic principles. One strategy that can be used is Islamic marketing. The principles of equity and justice for society's well-being are Islamic marketing's main ideas through collaborates ethics with value maximation. Islam increases living standards and creates value through ethical guidelines through respect and respect for individual freedom. Therefore, marketers should not deceive or exploit their customers, so honesty and openness are essential things in Islamic Ethics. If this is violated by injustice or fraud, the concept of brotherhood and humanity embraced by Muslims and forming Islam's vision will be lost [40]. Thus, Islamic marketing ethics guarantees the formation of harmony and satisfaction in conducting trade so that human dignity increases.

Based on the previous discussion, the current study's main aim is to identify the relationship between social media and Islamic marketing to customer satisfaction and loyalty and organize the main aspects considered over these studies and how such studies have addressed the related issues of social media and Islamic marketing.

\section{LITERATURE REVIEW}

\subsection{The Relationship of Social Media Marketing on Customer Satisfaction and Loyalty}

Brand image and loyalty need special attention and strategy to perform high achievement in social media marketing. It is needed more connection to costumer than selling activity. Therefore, it is called relationship marketing [20]. In this modern world, sellers should maintain customer relations using social media communication due to the hectic situation nowadays [20].

According to Lovelock and Yip [21], customer loyalty required satisfaction, and it has a positive correlation between loyalty and satisfaction [22]. Many studies also show that satisfaction is stimulated by loyalty, where the level of satisfaction comes from predictions between purchase intensity and consumer behavior towards related product brands [23]. It affects consumers' decision to repurchase a product [24] define satisfaction as an overall evaluation based on total purchase and consumption of experience with good or service over time. For Ref Razavi et al. [25], satisfaction is a satisfying consumer response. Satisfaction is related to perceptions that represent quality and depend on experience.

According to Lovelock and Wirtz [26], customer loyalty is measuring the consumer's behavior, in the long run, to continue buying, using, and recommending goods and services to other parties.

With the prevalence of e-commerce and website, brand loyalty is essential and beneficial for the firms to build using an online community where consumers can share their similarities and interact with others [27]. The online brand community makes consumers more trusted; therefore, it will develop brand loyalty [28].

Customer satisfaction leads to customer loyalty, and many researchers in marketing services show it [29, 30, $31,32,33$ ]. For instance, Crosby and Stephens [29] found that whether customers had replaced their insurance policies or allowed them to lapse depended on their prior satisfaction with the whole life coverage. Similarly, in their studies, $[34,35,36]$ in a sample of Islamic banking found that core-service satisfaction was positively associated with repurchase intentions.

\subsection{The Marketing Mix from Islamic Perspective and its impact to Customer Satisfaction and Loyalty}

According to Islamic views, trade-in line with Islamic teachings is an essential thing in human life. Prophet Muhammad SAW is an example of a successful entrepreneur before his prophetic life. Allah SWT is an example of Muslims' right way of life in daily life and trade $[37,38]$. Islam is a way of life, so that the code of conduct for business is also very well regulated. Commercial activity is set to become a comprehensive way of life in Islam. Islam has the Al-Quran and Hadith as the primary references for Islamic law. In both references, Islam instructs Muslims not to take usury and maintain the quality of their trading assets. Islam regulates trade with the following principles: (i) obey the moral rules that exist in the Koran and Hadith and (ii) refrain from cheating so that empathy and compassion for God's creation can be created [39]. 
The definition of Islamic marketing ethics is marketing based on the principles of justice and equal rights, which are not found in secular teachings [40]. Islam has three characteristics of market ethics. First, Islamic ethics allows marketing according to the wishes and interpretations as long as it does not violate the Quran. Second, the main difference is the metaphysical aspect, which is absolute and non-malleable. Third, maximizing the benefits and benefits of society must take precedence over maximizing profits. The existence of such characteristics makes marketing more done using conscience.

The concept of Islamic marketing generally has four characteristics, namely, spiritualistic, ethical, realistic, and humanistic [41]. A Muslim can discover the five pillars of Islam and their application to combine all of the above characteristics. This matter will then be discussed as follows.

- Spiritualistic. Al-Quran and sunnah must be the basis for business behavior is a form of spiritualism. So that Islamic marketers must fully believe that the Islamic law in the Koran and the Sunnah is the highest law used as a guide for all goodness [41, 42]. The spiritualistic concept has a core, namely, shahada. Shahada is the first pillar of Islam. By doing the shahada, a Muslim agrees with all the instructions and provisions of Allah SWT. Moreover, all actions will be held accountable in front of Allah SWT so that all aspects of marketing must be in line with Islamic teachings. However, the implementation may vary depending on the circumstances. Islamic marketers must be able to provide Islamic values in marketing carried out from planning to after-sales service. Ethical limits set by Islamic teachings must be applied in all marketing activities.

- Ethical. Islamic ethics contained in business transactions will be formed if there is a spiritual increase in Islamic marketing. It is referred to as ref [41] that one of the Islamic market characteristics is full of ethical considerations by following Al-Quran and Hadith's teachings. So this is referred to as Islamic ethics.

- $\quad$ Realistic. According to ref Sula and Kartajaya [41], Syariah marketers should not be so "rigid" in practicing Islamic marketing, for as long as it does not violate Islamic law. The content is more important than the appearance. However, it must be noted that being realistic does not mean that in the case of "emergency", Muslim marketers can do something which violates the principles of Islamic law. Ref Sula and Kartajaya [41] stated that Muslim marketers must be brave to differ themselves from any other Sharia marketing should not be so rigid as long as it does not violate Islamic law. However, notwithstanding the leniency in terms of implementation in current conditions, Muslim marketers should not do anything that violates the principles of Islamic law. The point is that Muslim marketers must have the courage to differentiate themselves from other marketers who do not use Islamic ethics in their marketing [41].

- Humanistic. Islam teaches humanism as a way to differentiate between humans and other creatures that inhabit this world. Consequently, humans are given reason and thoughts and lust but still have to keep away from greed [41]. Thus, Islamic marketing is thinking about profit and a process and strategy (wisdom) to meet needs through halal and good products. Not only that, but marketing in Islam also requires mutual agreement to achieve the welfare (Falah) of the buyer and seller to achieve material and spiritual prosperity [43]. So that there are four characteristics that marketers must have to market their goods and services, the four characteristics are:

1. Rabbaniyah (Theistic) is not owned by conventional marketing. These characteristics promote the principle of diniyyah or religion to marketers. This value comes from spiritual awareness, which is considered essential to color marketing activities that do not harm other parties.

2. Akhlaqiyah (Ethic) is something that must be owned by Islamic Marketers because marketing activities in Islam require moral values (morals and ethics). It is different from conventional marketing, which often does not use moral values as guidelines to do everything. Akhlaqiyah, which is derived from the rabbaniyah concept, applies to all humans regardless of religion.

3. Al-Waqiyyah (Realistic) means Islamic marketing is not exclusive marketing, fanatical towards particular groups, anti-renewal or modernity, and not flexible to environmental changes. Marketing concepts that are flexible and realistic to be applied to the basic concepts of Islamic marketing.

4. Al-Insaaniyyah (Humanistic) explained that Islamic marketing specialization is humanistic. Al-Insyaaniyyah is sharia that was created to prioritize human values and maintain humanity. Islamic marketers with Al-Insaaniyyah values will be controlled and tawazun (balanced). 


\subsection{Hypothesis Development}

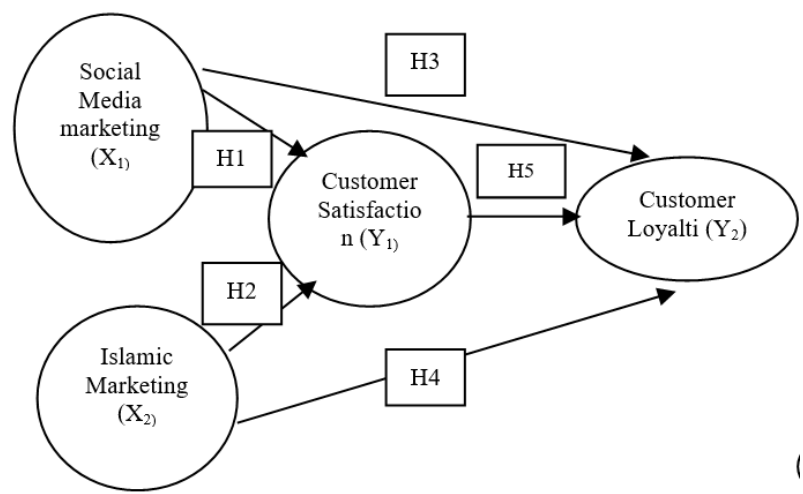

Figure 1. The Impact of Social Media and Islamic Marketing Towards Customer Satisfaction and Customer Loyalty

\section{Explanation:}

H1 : Social media marketing has a positive significant impact on customer satisfaction

$\mathrm{H} 2$ : Islamic marketing has a positive significant impact on customer satisfaction

H3 : Social media marketing has a positive significant impact on customer loyalty

H4 : Islamic marketing has a positive significant impact on customer loyalty

H5 : Customer satisfaction has a positive significant impact on customer loyalty

\section{METHODS}

This research was using explanatory and quantitative methods. The sample was drawn from a group of 3 hijab online shop customers in Malang. In order to determine the sample size, this research was using snowball sampling due to the unknown population. Questioners were distributed to 140 respondents and scaled using a five-point Likert format, where the anchor of 1 indicates "strongly disagree" and 5 indicates "strongly agree". There are two samples criteria for respondents in this research namely the customers of hijab online shop whose having transaction more than or equal with three times and become at least a year-customers.

\section{RESULTS}

\subsection{Descriptive analysis}

The customers from 3 hijab online shop in Malang were come from different ages range even though mostly they are in the range 20-30 years old. The gender is largely women in various income. Generally, those customers not only become a year customer but also, they are repeating to buy in hijab online shops more than 3 times. They are using social media as their tools in having transactions instead of choosing a direct shop.

\subsection{Path Analysis}

Follows the equation of path analysis diagram result in this research:

Sub Structure I: $\mathrm{Y}_{1}=0.417 \mathrm{X} 1+0,360 \mathrm{X} 2$

Sub Structure II: $\mathrm{Y}_{2}=0.359 \mathrm{X} 1+0.390 \mathrm{X} 2+0.165 \mathrm{Y}_{1}$

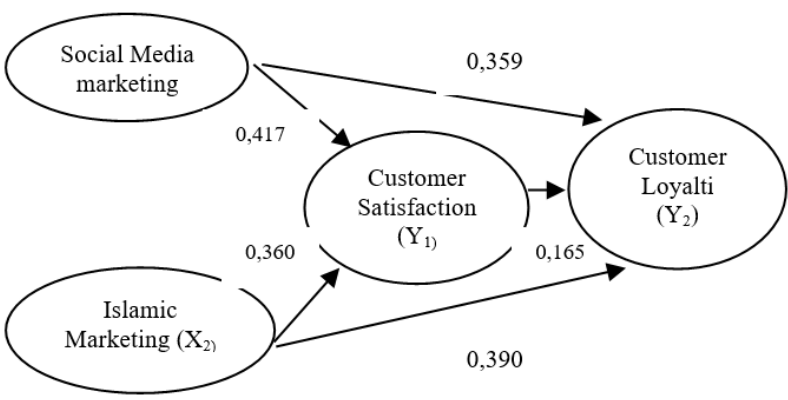

Figure 2. The result of path analysis

There are two impacts of this test, first is indirect impact and second is total impact. The indirect impact in this test result comes in two relationships of variables. The beginning is the indirect impact of social media marketing on customer loyalty through customer satisfaction result is 0.068 . The last is the indirect impact of Islamic marketing on customer loyalty through customer satisfaction result is 0,059. Furthermore, the total impact is overall impact of the entire path. For the relationship between social media on customer loyalty through customer satisfaction have number 0,427. Based on the result, as the intervening variable, customer satisfaction strengthens the impact of social media on customer loyalty. On the other hand, customer satisfaction as an intervening variable positively affects customer loyalty due to the number of 0,449 .

\section{DISCUSSION}

\subsection{The Impact of Social Media marketing on Customer Loyalty Through Customer Satisfaction}

Social media have a massive influence on the online shop since it links the interaction between seller and buyer. Thus, through the most appropriate mechanism. Important information is broadcast. To reach the maximum impact on this news broadcasting, the seller should communicate the new information correctly and decide which information is the most useful to the customers. This communication aims to satisfy customers who will connect and interact with the seller and lead to engagement progress.

An intermediate step to reach the organization's goal should be to conduct even though customer satisfaction surveys and ratings could capture the impact [44]. Another argument suggests that the marketing goals are not based on customer satisfaction, but also the customer empowerment with the seller, which could 
construct their desires and products [45]. Satisfaction is an essential condition but not adequate for customer engagement.

Satisfaction, including interactions through a buying activity, could lead to the purchase, while disappointment in between could interrupt the process and caused customer exit.

However, satisfaction will not guarantee repurchases activity and long-term relationships. There are differences between transaction-specific and cumulative customer satisfaction. Cumulative Satisfaction is explained as "a total evaluation based on the whole procurement and consumption activity that satisfies service over the period" [46]. A tremendous level of Satisfaction is obtained when customer expectations are very high. Certain emotions will also appear and describe as a satification act, and as delight [47].

After customer satisfy in multiple times during a purchase, the next step is customer retention. This can be a result of both overall satisfaction across a period or intensely positive emotions. Satisfaction over time appears due to repurchases and indicates a long-term relationship between buyer and seller yet does not certainly guarantee the presence of highly positive feelings for each other. From a different perspective, the customer's high positive reaction does not show the seller and buyer's long-term relationship. If this condition happens, the retention may appear from taking relationships without emotional bonds or emotional connections outwardly a long-term relationship. Next, retention can become a customer loyalty when the customer have emotional bonds. This can prove by the path result that social media marketing is affecting on customer loyalty more stronger if there is customer satisfaction as an intervening variable.

\subsection{The Impact of Islamic Marketing on Customer Loyalty Through Customer Satisfaction}

Loyalty is a central dimension of brand assets. Ref Aaker [48] describes that brand loyalty is customer affection for a specific brand. There are several levels of loyalty. First, behavioral loyalty is consumer behavior to marketplace measured based on the number of repeated purchases [49] or rebuy the same brand as the best option [47]. Second, cognitive loyalty is described as the consumers' first choice. This cognate loyalty happened when customers need a purchase decision, and the specific brand up first in the customer's mind.

Islamic ethics in selling behavior plays a vital role in developing customer loyalty. In a theoretical perspective [35], unethical sales behavior is a short-run, convenient perspective void of every sense of social responsibility. Furthermore, ref Gundlach and Murphy [50] explains that developing ethical principles permits marketers to encourage long-term relationships with clients. Equity theory examines Islamic ethical sales behavior as an investment in the equity formulation. One of the findings in this research is Islamic marketing has a strong impact to customer loyalty with customer satisfaction as an intervening variable rather than direct impact from Islamic marketing to customer loyalty itself. This result is supported by ref Hassan et al. [51], where satisfaction with the core service impacts satisfaction. In turn, both variables lead to loyalty. In conclusion, Satisfaction with the Islamic bank leads to trust, while trust is proposed to develop customer loyalty.

\subsection{The Impact of Social Media Marketing on Customer Satisfaction}

Social media has a significant impact on customer satisfaction and it is strengthening the finding of [52]. Information communication between sellers and customer satisfaction played important roles in previous literature by [53]. It's proven that social media has an essential influence on customer satisfaction, strengthening the finding of [52]. Information communication among traders and buyer satisfaction has previously been verified in the literature by Agnihotri et al. [53], the research study about how far shop sellers know and how they use technology. The more expert online shop seller and utilize the technology, customer satisfaction will depend on information communication. Accurate and relevant information from the seller will become the primary basis for buyers' satisfaction. Ref Agnihotri et al. [53], proved that online shop sellers' information communication positively impacts customer satisfaction. Online shop sellers' adequately communicate information that is important to the customer. The data shows that a positive relationship between responsiveness and customer satisfaction indicates that customers appreciate sellers' up-to-date responses.

\subsection{The Impact of Islamic Marketing on Customer Satisfaction.}

Variable of Islamic marketing significantly impact customer satisfaction. When the Islamic marketing level is developed, customer satisfaction will also be increased. In this research, the satisfication of online shop customers' satisfaction increases because Islamic marketing promotes using Islamic values. This results in line with the spiritual marketing process. The spiritual marketing process describes how spiritual marketing can deliver customer satisfaction and loyalty to the company [51]. This Spiritual Values on Marketing based can win many share of customers which finally deliver customer satisfaction. 
According to Shahi and Javanmard [54] Islamic ethics as part of Islamic marketing also influence customer satisfaction. Thus, sharia business organizations should perform ethics following Islamic principles.

\subsection{The Impact of Social Media Marketing on Customer Loyalty}

Develop and maintain brand loyalty are essential issues for marketers over a period.

Marketers use various ways to manage the customer's brand loyalty, and one of the ways is by using social media. If the social media level is increased, customer loyalty is also increasing. These findings support online marketing theory such as E-WOM, Online Communities, and Online Advertisement, which influences brand and product promotion through the company website and social media platforms. Marketers play advocacy roles in relationships. Ref Urban [55] implies that digital technologies, i.e., the internet, have shifted the emphasis from relationship marketing with slogans like "customer care" and "delight your customer" to performing in the buyers' best interests and becoming advocates for them. Sellers should decide the best product for their customers even if those offerings are from competitors. Urban [55] Mention that a company that advocates customers will reciprocate their loyalty, trust, and purchases both now or later. Customers, in turn become advocates for sellers among those with who they have connections and interactions. In the future, sellers and customers are expected to look after each other's interests, and the focus will be on the exchange of values that transcend their selfinterest [56].

Different studies prove that social media marketing significantly impacts customer loyalty from profitable campaigns on social media. This variable is the most notable brand loyalty drivers, accompanied by the relevancy of the content, reputation of the range, and performing and providing applications on different social media platforms. Another variable that has a significant impact on social media marketing is the type of content. The results imply that people share technical and instructive information, along with music, funny, and extraordinary things. This is shows that social media is a stage where people want to entertain themselves, escape from the harsh facts of life, search for sincerity and fun, and share information and instructions.

\subsection{The Impact of Islamic Marketing on Costumer Loyalty}

Islamic marketing significantly impacts customer loyalty. When the level of Islamic marketing increases, following customer loyalty also increases. This research is in line with a study conducted by Shahi and Javanmard [54], which states Islamic business ethics, which part of
Islamic marketing has a significant impact on customer loyalty. According to Hassan and Harahap [57], customer loyalty is the key to success in the short term and longterm. Commitment has an essential value for the company; thus, online shops have to increase customer loyalty to improve Islamic marketing.

\subsection{The Impact of Customer Satisfaction on Customer Loyalty}

The result of path analysis shows that customer pleasure has a significant influence on buyer loyalty. This considerable impact shows the level of customer satisfaction is influence by the increase in customer loyalty. Findings from Naser et al. [58] with research on Jordan Islamic bank customers show that customer satisfaction has a significant positive impact on bank loyalty. Results from Jamal and Naser [59] using the sample from different service industries also offer the same product where the positive influence of customer satisfaction. These positive terms happened to both customer satisfaction with the Islamic bank as a service provider and the core service on customer intention to use the facility's services again, and recommend the Islamic service bank to a friend. There is a longterm orientation in this variable, since trust is also conceptualized as "a cumulative process that develops throughout repeated, successful interactions" [60]. Satisfying encounters are hypothesized to reinforce customers' confidence in the Islamic bank [61]. A highly satisfying experience with the Islamic bank may reassure the customer that his trust in the service provider is well placed and enhance it [35]. Empirical research in marketing channels [62] and the consumer behavior literature [63] supports this contention. Due to the Islamic banking system's unique characteristics, a customer will get natural satisfaction from most aspects of an Islamic bank's products and services. Islamic banks thus have a competitive advantage in terms of enjoying customer confidence. For example, satisfied customers are likely to engage in repeat purchases and reflect strong loyalty towards the Islamic bank. As argued by ref [64, 65] satisfied customers like these are likely to engage in positive word of mouth and try line extensions. Since satisfaction is an essential component of the total package of value required by customers, Islamic banks can use a segment of satisfied customers in its promotional materials to attract new customers. An Islamic bank can also use images of its caring employees. Employees are a significant part of the service delivery process and play a significant role in company-customer interaction. Furthermore, an Islamic bank can promote its products using physical evidence in its promotional material about most of the facilities provided by Islamic banks. 


\section{CONCLUSIONS}

Based on research that has been conducted by the researcher can be concluded as follows:

1. Social media has significant impact on customer satisfaction

2. Islamic marketing has significant impact on customer satisfaction.

3. Social media has significant impact on customer loyalty

4. Islamic marketing has significant impact on customer loyalty

5. Customer satisfaction has significant impact on customer loyalty.

\section{REFERENCES}

[1] Wearesocial, Indonesia: The Essential Data You Need To Understand Mobile, Internet, and Social Media Use.[Online]. Available: https://wearesocial.com/global-digital-report-2019, Accessed: Aug, 18, 2019

[2] A. A. Alalwan, N. P. Rana, R. Algharabat, A. Tarhini, Systematic Review of Extant Literature in Social Media in the Marketing Perspective, The Good, the Bad, and the Ugly - 15th IFIP WG 6.11 Conference on e-Business, e-Services and e-Society I3E 2016, Proceedings, Springer Verlag, United Kingdom, , vol. 9844 LNCS, Sept 2016, p.p 78-79.

[3] Y. K. Dwivedi, K.K. Kapoor, H. Chen, Social media marketing and advertising, The Marketing Review, United Kingdom: Westburn Publisher Ltd, Vol. 15(3), June 2015, pp. 289-309.

[4] A. K. Rathore, P. V. Ilavarasan, Y. Dwivedi, Social media content and product co-creation: an emerging paradigm, Journal of Enterprise Information Management, Melbourne: Emerald Group Publishing Limited, vol. 29(1), Feb 2016, pp. 7-18.

[5] D. G. Taylor, E. L. Jeffery, D. Strutton, Friends, Fans, and Followers: Do Ads Work on Social Networks? How Gender and Age Shape Receptivity, Journal of Advertising Research, America: WARC for the ARF, vol. 51(1), March 2011, pp. 258-76.

[6] Y.Q. Zhu, and H.G. Chen, Social media and human need satisfaction: Implications for social media marketing, Business Horizons, Indiana: Elsevier, vol. 58(3), 2015, pp. 335-345.

[7] A. A. Alalwan, N. P. Rana, Y. K. Dwivedi, R. Algharabat, Social Media in Marketing: A Review and Analysis of the Existing Literature, Telematics and Informatics, Amsterdam: Elsevier Ltd, vol. 34(7), November 2017, pp. 1177-1190.

[8] R. Algharabat, A. A. Alalwan, N.P. Rana, Y. K. Dwivedi, Three dimensional product presentation quality antecedents and their consequences for online retailers: The moderating role of virtual product experience, Journal of Retailing and
Consumer Services, Amsterdam: Elsevier Ltd, vol. 36, May 2017, pp. 203-217.

[9] S. S. Abed, Y. K. Dwivedi, M.D. Williams, Social media as a bridge to E-Commerce adoption in SMEs: a systematic literature review, The Marketing Review, United Kingdom: Westburn Publisher, vol. 15(1), 2015, pp. 39-57.

[10] K. Hawkins and P. Vel, Attitudinal loyalty, behavioural loyalty and social media: An introspection, The Marketing Review, United Kingdom: Westburn Publisher Ltd, vol. 13(2), 2013, pp. 125-141.

[11] O. Hinz, B. Skiera, C. Barrot, J. U. Becker, Seeding strategies for viral marketing: An empirical comparison, Journal of Marketing, : SAGE Publishing, vol. 75(6), Nov 2011, pp. 55-71.

[12] K. Usher, C. Woods, E. Casella, N. Glass, R. Wilson, L. Mayner, E. Cummings, Australian health professions student use of social media, Collegian, Australia: Elsevier Ltd, vol. 21(2), June 2014, pp. 95-101

[13] B. Zeng and R. Gerritsen, What do we know about social media in tourism? A review, Tourism Management Perspectives, Australia: Elsevier Ltd, vol. 10, April 2014, pp. 27-36.

[14] K. Filo, D. Lock, A. Karg, Sport and social media research: A review, Sport Management Review, Australia: Elsevier Ltd, vol. 18(2), May 2015, pp 166-181.

[15] A. Saxena and U. Khanna, Advertising on social network sites: A structural equation modelling approach, Vision: The Journal of Business Perspective, SAGE Publications, vol. 17(1), March 2013, pp. 17-25

[16] S. Okazaki and C.R. Taylor, Social media and international advertising: theoretical challenges and future directions, International marketing review, Melbourne: Emerald Insight, vol. 30(1), Feb 2013, pp. 56-71.

[17] P. S. Leeflang, P.C. Verhoef, P. Dahlström, T. Freundt, Challenges and solutions for marketing in a digital era, European Management Journal, Australia: Elsevier Ltd, vol. 32(1), Feb 2014, pp. 112.

[18] D.E. Schultz and J. Peltier, Social media's slippery slope: challenges, opportunities and future research directions, Journal of Research in Interactive Marketing, Melbourne: Emerald Insight, vol. 7(2) May 2013, pp. 86-99.

[19] Central Bureau of Statistics, 2017

[20] S. Gordhamer, 4 Ways Social Media is Changing Business, retrieved from http://Mashable.com/2009/09/22/Social-MediaBusiness/, 2009.

[21] C. H. Lovelock and G. S. Yip. Developing Global Strategies For Service Businesses, SAGE Journal, 
California Management Review, vol. 38(2), 1996, pp. 64-86.

[22] K.C. Hu and M.C. Huang, Effects of Service Quality, Innovation and Corporate Image on Customer's Satisfaction and Loyalty of Air Cargo Terminal, International Journal of Operations Research, 8, Inderscience Enterprises Ltd.United Kingdom, 2011, pp. 36-47.

[23] Z.U. Chandio, M.A Qureshi, S. Ahmed, Brand trust, customer satisfaction and Brand Loyalty-a cross Examination, Journal of Business Strategies, Karachi : Greenwich University, Vol.9(1), 2015, pp 63-82.

[24] E.W.Anderson, C.Fornell, D.R.Lehmann, Customer Satisfaction, Market Share, and Profitability: Findings from Sweden, Journal of Marketing Vol. 58, No. 3, Sage Publications, Inc:United States of America, July 1994, pp. 53-66.

[25] S. M. Razavi, H. Safari, H. Shafie, K. Khoram, Relationships among Service Quality, Customer Satisfaction and Customer Perceived Value: Evidence from Iran's Software Industry, Journal of Management and Strategy Vol.3(3), Sciedu Press:Canada, June 2012, pp.28-37.

[26] C. H. Lovelock and J. Wirtz, Services Marketing: People, Technology, Strategy, 7th edition, Prentice Hall : United states. pp 78-85

[27] A. Armstrong and J. Hagel, Net Gain: Expanding Markets Through Virtual Communities, 1997. [Online]. Available: http://www.techsoc.com/netgain.htm, Accessed: Aug. 17, 2019.

[28] W. M. Hur, K. H. Ahn, M. Kim, Building brand loyalty through managing brand community commitment. Management Decision Vol. 49(7), Emerald Publishing, 2011, pp. 1194-1213.

[29] L.A.Crosby and N. Stephens, Effects of Relationship Marketing on Satisfaction, Retention, and Prices in the Life Insurance Industry, Journal of Marketing Research, Vol. 24(4), American Marketing Association, Nov 1987, pp. 404-411.

[30] J.J. Cronin and S.A. Taylor, Measuring Service Quality: A Reexamination and Extension, Journal of Marketing Vol. 56(3), Sage Publications, Inc : United States of America, July 1992, pp. 55-68.

[31] S.A. Taylor and T.L. Baker, An assessment of the relationship between service quality and customer satisfaction in the formation of consumers' purchase intentions, Journal of Retailing vol 70(2), Elsevier, 1994, pp. 163-178.

[32] P.A. Dabholkar, Framework For Service Quality, Sage Publications: Boston, 2000, pp. 56-75

[33] V.Liljander and J. Mattson, Impact of Customer Preconsumption Mood on the Evaluation of Employee Behavior in Service Encounters, Psychology and Marketing Vol. 19(10), Oct 2002, pp. 837-860.
[34] P. Gerrard and J. B. Cunningham, Islamic Banking: a study in Singapore, International Journal of Bank Marketing Vol. 15(6), Emerald, 1997, pp. 204-216.

[35] S.Metawa and M.Al-Mossawi, Banking behavior of Islamic bank customers: Perspectives and implications, International Journal of Bank Marketing Vol.16(7), Emerald, Dec 1998, pp. 299313.

[36] K.Naser, A.Jamal, K. Al-Khatib, Islamic banking: a study of customer satisfaction and preferences in Jordan, International Journal of Bank Marketing Vol. 17(3), Emerald, 1999, pp. 135-151.

[37] M.S. Antonio, Muhammad SAW: The Super Leader Super Manager, Prophetic Leadership and Management Centre: Jakarta, 2007, pp. 75-80.

[38] A.Trim, Business Wisdom of Muhammad SAW: 40 Business Breakthrough of Prophet SAW, Madania Prima: Bandung, 2008, pp. 35-47.

[39] L.A.K. Niazi, Islamic Law of Contract No. 2, Research Cell, Dayal Sing Trust Library: Lahore, 1996, pp. 39-62.

[40] M. Saeed, Z. U. Ahmad, S. M. Mukhtar, International Marketing Ethics from an Islamic Perspectives: A Value Maximization Approach, Journal of Business Ethics, Switzerland: Springer Nature, vol. 32, July 2001, pp. 127-142.

[41] M.S Sula and H. Kartajaya, Syariah Marketing, $1^{\text {st }}$. ed. Penerbit Mizan : Bandung, 2006, pp. 7-22.

[42] Sharing, Marketing Shariah, Apa Sih Bedanya?(Shariah marketing, what is the difference?), Sharing, October 2006, pp. 46-7.

[43] M.M. Alom and M.S. Haque, Marketing: An Islamic Perspective, World Journal of Social Sciences Vol. 1(3). Sciedu Press: Canada, July 2011, pp. 71-81.

[44] V.Mittal and W. Kamakura, Satisfaction, Repurchase Intent, and Repurchase Behavior: Investigating the Moderating Effect of Customer Characteristics, Journal of Marketing Research Vol. 38(1), Sage Journals: United States of America, 2001, pp. 131-142.

[45] A.F.Firat and N. Dholakia, Theoretical and philosophical implications of postmodern debates: some challenges to modern marketing, Publishing: United States of America, June 2006, pp. 123-162.

[46] E.W.Anderson, C.Fornell, D.R.Lehmann, Customer Satisfaction, Market Share, and Profitability: Findings from Sweden, Journal of Marketing Vol. 58(3), Sage Publications, Inc:United States of America, July 1994, pp. 53-66.

[47] R.L. Oliver, Satisfaction: A Behavioral Perspective on the Consumer, McGraw Hill: United States, 1997, pp. 233-5.

[48] D.A. Aaker, Managing Brand Equity; Capitalizing on the Value of a Brand, The Free Press: New York, 1991, pp. 75-77. 
[49] K.L. Keller, Strategic Brand Management: Building, Measuring and Managing Brand Equity, Prentice Hall : United States, 1998, pp. 253-255.

[50] G. Gundlach and P.E. Murphy, Ethical and Legal Foundations of Relational Marketing Exchanges, Journal of Marketing Vol. 57, Sage Publishing : United States, 1993, pp. 35-46.

[51] A. Hassan, A. Chachi, A. S. A. Latiff, Islamic Marketing Ethics and Its Impact on customer satisfaction in the Islamic Banking Industry, JKU: Islamic Econ, vol. 21(1), 2008, pp. 27-46.

[52] R. Agnihotri, R. Dingus, M. Hu, M. Krush, Social Media: Influencing customer satisfaction in B2B sale, Industrial Marketing Management, Amsterdam: Elsevier Ltd, vol. 53, Feb 2016, pp. 172-180.

[53] R. Agnihotri, A.Rapp, K.J. Trainor, Understanding the role of information communication in the buyerseller exchange process: Antecedents and outcomes, Journal of Business \& Industrial Marketing Vol. 24(7), Emerald, August 2009, pp. 474-486.

[54] K. Shahi and Javanmard, Impact of Islamic Ethics Iranian on Customer Satisfaction Index Model, Indian Journal Science Research vol.4(6), 2014, pp. 373-380.

[55] G.L. Urban, The emerging era of customer advocacy, MIT Sloan Management Review, Vol. 45(2), Massachusetts Institute of Technology: United States, 2004, pp. 77-82.

[56] F. Nordin,Transcendental marketing: a conceptual framework and empirical examples, Management Decision Vol. 47(10), Emerald Group Publishing Ltd: United Kingdom, 2009, pp.1652 - 1664.

[57] A.Hassan and S.S.Harahap, Exploring corporate social responsibility disclosure: the case of Islamic banks, International Journal of Islamic and Middle Eastern Finance and Management Vol. 3(3),
Emerald Group Publishing Limited, 2010, pp. 203227.

[58] K. Naser, A. Jamal, K. Al-Khatib, Islamic banking: a study of customer satisfaction and preferences in Jordan, International Journal of Bank Marketing Vol. 17(3), Emerald, 1999, pp. 135-151.

[59] A. Jamal and K. Naser, Factors Influencing Customer Satisfaction In The Retail Banking Sector in Pakistan, International Journal of Commerce and Management Vol. 13(2), Emerald Publishing Limited, 2003, pp. 29-53.

[60] C.Y.Nicholson, L.D. Compeau, R. Sethi The role of interpersonal liking in building trust in long-term channel relationships, Journal of the Academy of Marketing Science Vol 29(1),Springer, 2001, pp.315.

[61] S.N.A, Haron and S.Planisek, Bank Patronage Factors of Muslims and non- Muslim customers, International Journal of Bank Marketing Vol 12 (1),Emerald Group Publishing, 1994, pp.32-40.

[62] S. Ganesan, Determinants of Long-Term Orientation in Buyer-SellerRelationships, Journal of Marketing Vol. 58, Sage Publisher: United States, April 1994, pp. 1-19.

[63] E. Garbarino and M. Johnson, The Different Roles of Satisfaction, Trust, and Commitment in Customer Relationships. Journal of Marketing Vol.63, Sage Publisher: United States, April 1999, pp. 70-87.

[64] R, East, Consumer behaviour: Advances and applications in marketing Prentice Hall: London, 1997, pp. 85-90.

[65] M.L, Richens, Negative word of mouth by dissatisfied consumers: A pilot study. Journal of Marketing Vol. 47(1), Sage Publishing: United States, 1983, pp.68-78. 